\title{
EFFECT OF GLUTAMINE SUPPLEMENT ADMINISTRATION ON THE REDUCTION OF MUSCULAR FATIGUE POST-ECCENTRIC EXERCISE
}

\author{
Afif Rusdiawan, Taufikkurrachman \\ Department of Physical Education, Health and Recreation, Faculty of Mathematics and Sciences Education, IKIP Budi \\ Utomo, Malang, Indonesia
}

\section{ABSTRACT}

Eccentric activity can cause pain due to muscle damage and fatigue. Tired and damaged muscular state will degrade athletes' performance during a competition. Glutamine supplements are known to maintain plasma protein levels and can also improve muscle weakness due to inflammation that occurs after eccentric activity. The purpose of this study was to prove the effect of glutamine supplementation on the reduction of muscle fatigue after eccentric activity based on muscle strength and joint ROM. The subjects of this study were students of PJKR, IKIP Budi Utomo, who were randomly divided into 2 groups, the control group (K1) and treatment group (K2), each consisting of 22 respondents. The design of this research is randomized grsoup pre-test and post-test design. The eccentric activity performed was drop jumps on the bench with a height of 0.5 meters. Glutamine was administered orally after eccentric activity with a dose of 0.4 grams $/ \mathrm{kg} \mathrm{BW}$ in $450 \mathrm{ml}$ water mineral 3 times (3 days). Measurement of Leg muscle strength was performed using Back and Leg Dynamometer by pulling with all the strength using leg muscles, whereas ROM measurements were measured using a goniometer performed on the knee joint in a passive way. The result of measurement obtained the mean of muscle strength of control group $63.7 \pm 17.0 \mathrm{~kg}$ and treatment group $81.1 \pm 17.0 \mathrm{~kg}$ at 72 hours. While result of ROM measurement obtained the mean of control group $124.3 \pm 3.2$ degrees and treatment group $131.7 \pm 4.1$ degrees at 72 hours. The analysis showed that glutamine administration in treatment group after eccentric activity increased leg muscle strength with $p=0.000$, and also increased knee joint ROM with $p=0.000$ at 72 hours after eccentric activity. In conclusion, glutamine administered with a dose of 0.4 gram/kg BW/day can increase leg muscle strength and knee joint ROM at 72 hours after eccentric activity.

Keywords: Eccentric activity; glutamine; leg muscle strength; knee joint ROM

\section{ABSTRAK}

\begin{abstract}
Aktivitas eksentrik dapat menyebabkan rasa sakit karena kerusakan otot dan kelelahan. Kondisi otot yang lelah dan rusak akan menurunkan kinerja atlet selama kompetisi. Suplemen glutamin diketahui menjaga kadar protein plasma dan juga dapat meningkatkan kelemahan otot karena peradangan yang terjadi setelah aktivitas eksentrik. Tujuan dari penelitian ini adalah untuk membuktikan efek suplementasi glutamin pada pengurangan kelelahan otot setelah aktivitas eksentrik berdasarkan kekuatan otot dan ROM sendi. Subjek penelitian ini adalah mahasiswa PJKR, IKIP Budi Utomo, yang secara acak dibagi menjadi 2 kelompok, kelompok kontrol (K1) dan kelompok perlakuan (K2), masing-masing terdiri dari 22 responden. Desain penelitian ini adalah grsoup pre-test dan post-test secara acak. Aktivitas eksentrik yang dilakukan adalah drop jumps di bangku dengan ketinggian 0,5 meter. Glutamin diberikan secara oral setelah aktivitas eksentrik dengan dosis 0,4 gram/kg BB dalam $450 \mathrm{ml} \mathrm{mineral} \mathrm{air} 3 \mathrm{kali}$ (3 hari). Pengukuran kekuatan otot tungkai dilakukan menggunakan Back dan Leg Dynamometer dengan menarik dengan semua kekuatan menggunakan otot tungkai, sedangkan pengukuran ROM diukur menggunakan goniometer yang dilakukan pada sendi lutut dengan cara pasif. Hasil pengukuran diperoleh rerata kekuatan otot kelompok kontrol 63,7 $\pm 17,0 \mathrm{~kg}$ dan kelompok perlakuan 81,1 $\pm 17,0$ kg pada 72 jam. Sedangkan hasil pengukuran ROM diperoleh rerata kelompok kontrol 124,3 $\pm 3,2$ derajat dan kelompok perlakuan 131,7 \pm 4,1 derajat pada 72 jam. Analisis menunjukkan bahwa pemberian glutamin pada kelompok perlakuan setelah aktivitas eksentrik meningkatkan kekuatan otot tungkai dengan $p=0,000$, dan juga meningkatkan ROM sendi lutut dengan $p=0,000$ pada 72 jam setelah aktivitas eksentrik. Kesimpulannya, glutamin yang diberikan dengan dosis 0,4 gram/kg BB/hari dapat meningkatkan kekuatan otot tungkai dan ROM sendi lutut pada 72 jam setelah aktivitas eksentrik.
\end{abstract}

Kata kunci: Aktivitas eksentrik; glutamin; kekuatan otot tungkai; ROM sendi lutut

Correspondence: Afif Rusdiawan, Dukuh Pundong RT 02 RW 05 Diwek, Jombang, Indonesia. Phone: 085731141139 E-mail: rusdiawan.a@gmail.com

pISSN:2355-8393 • eISSN: 2599-056x • doi: http://dx.doi.org/10.20473/fmi.v55i4.17320

- Fol Med Indones. 2019;55:275-279 • Received 24 May 2018 • Accepted 15 Nov 2018

- Open access under CC-BY-NC-SA license • Available at https://e-journal.unair.ac.id/FMI/ 


\section{INTRODUCTION}

Eccentric exercise is one type of resistance exercise that often cause pain and muscle fatigue. This is because, when performing eccentric exercises, muscles undergo maximum elongation in order to generate maximum power (Burnley et al 2010). In addition, during he eccentric exercise there is an increase in tension of the muscle compared to isometric or isotonic exercise. The resulting stress resulted in frequent damage and reduction in muscle strength (Bompa 1999).

Glutamine supplements are known to maintain muscle protein levels and play a role in immunity (Roth 2008). Glutamine supplements can also improve muscle weakness due to inflammation that occurs after eccentric exercise (Paulsen et al 2010). Recent studies have found that glutamine supplements are highly effective in reducing muscle fatigue as indicated by increased muscle strength after eccentric exercise (Street et al 2011).

Therefore, this study was conducted to determine the effect of glutamine supplementation on the reduction of muscle fatigue after eccentric exercise. In this study the assessment of muscle fatigue was performed by indirect method, ie measurement of muscle strength and joint ROM. The measured muscle strength was in leg muscle, while the ROM was measured at knee joint (flexion and extension).

\section{MATERIALS AND METHODS}

This study was a laboratory experimental study with randomized group pre-test and post-test design. Subjects in this study were students of PJKR, IKIP Budi Utomo, Malang, which were randomly divided into 2 groups, the control group (K1) and treatment group (K2). Prior to data collection, the subjects were asked to fast for 8 hours while still consuming mineral water. Then, the initial measurement (pre test) of leg muscle strength and knee joint ROM was performed. After the pre-test was done, the subjects were given breakfast with the same amount and type before performing eccentric activity. Furthermore, 2 hours after breakfast, the subjects performed eccentric activity in the form of drop jump activity (up and down stool as high as $50 \mathrm{~cm}$ ) as much as 10 reps and 10 sets with intervals of 1 minute per set. One hour after eccentric activity, limb leg muscle strength and knee joint ROM were measured in both study groups (post-test 1 ). Immediately after post-test 1 , the administration of glutamine was performed in the treatment group and mineral water in the control group. Furthermore, measurements of leg muscle strength and knee joint ROM were performed 24 hours after eccentric activity (post-test 2). After post-test 2, glutamine was administered immediately and measurements of leg muscle strength and knee joint ROM 48 hours were performed again after eccentric activity (post-test 3 ). After post-test 3, glutamine was administered immediately again and measurements of leg muscle strength and knee joint ROM 72 hours were performed again after eccentric activity (post-test 4).

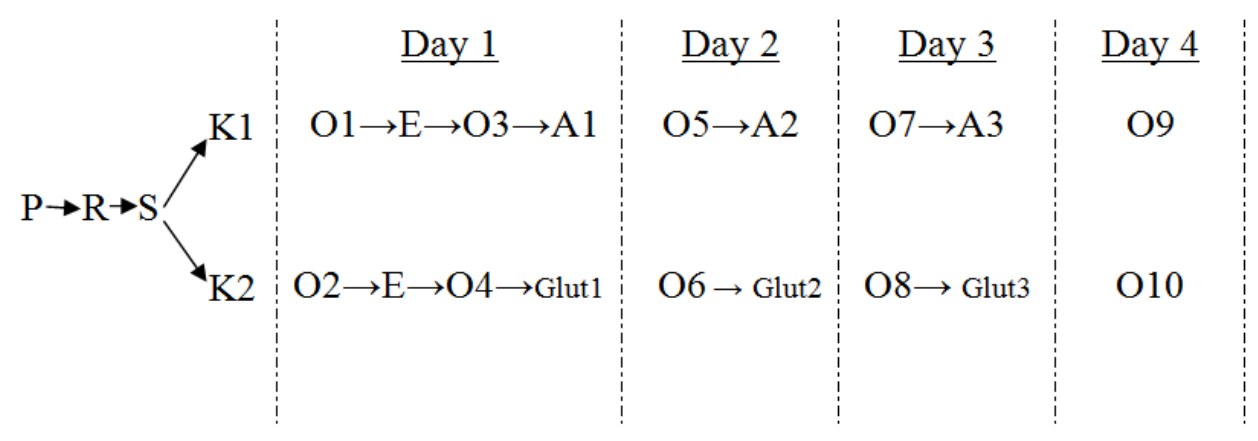

Fig. 1. Flowchart of the study. P: Research population, S: Research sample, R: Randomization, K1: Control group (mineral water $450 \mathrm{ml}$ ), K2: Treatment group (glutamine $0.4 \mathrm{gram} / \mathrm{Kg} \mathrm{BW}$ ), $\mathrm{O} 1$ and $\mathrm{O} 2$ : Pre-test on $\mathrm{K} 1$ and $\mathrm{K} 2$, O3 and O4: Post-test I on K1 and K2 (1 hour after eccentric activity), O5 and O6: Post-test II on K1 and K2 (24 hours post exercise), $\mathrm{O} 7$ and O8: Post-test III on KI and K2 (48 hours post exercise), O9 and O10: Post-test III on KI and K2 (72 hours post exercise), E: Eccentric activity (10 jump drop 10 sets of reps), Glut 1: Glutamine administration immediately after post test I, Glut 2: Glutamine administration 24 hours after eccentric activity, Glut 3: Glutamine administration 48 hours after eccentric activity, A1: Mineral water administration immediately after post test I, A2: Mineral water administration 24 hours after eccentric activity, and A3: Mineral water administration 48 hours after eccentric activity. 


\section{RESULTS}

Data retrieval produced primary data and supporting data, ie weight, height, leg muscle strength, and knee joint ROM.

Table 1. Weight and height descriptive test

\begin{tabular}{ccc}
\hline Variables & Control & Treatment \\
\hline Bodyweight $(\mathrm{kg})$ & $60.50 \pm 4.51$ & $59.46 \pm 4.14$ \\
Bodyheight $(\mathrm{cm})$ & $169.09 \pm 3.91$ & $168.18 \pm 5.88$ \\
\hline
\end{tabular}

Paired t test results on leg muscle strength in control group showed decreased limb muscle strength occurred after 1 hour, 24 hours, 48 hours and 72 hours post eccentric activity. However at 72 hours an increase in leg muscle strength from 24 hours and 48 hours. In treatment group, a decrease in leg muscle strength also occurred at 1 hour, 24 hours, 48 hours and 72 hours after eccentric activity. However, at 72 hours an increase in leg muscle strength occurred from 1 hour, 24 hours and 48 hours. (Fig. 2, Table 3).

Table 2. Descriptive test of leg muscle strength (Kg)

\begin{tabular}{ccc}
\hline $\begin{array}{c}\text { Leg muscle } \\
\text { strength }\end{array}$ & Control & Treatment \\
\hline Pretest & $74.5 \pm 19.8$ & $84.6 \pm 16.6$ \\
Post test 1 & $64.3 \pm 21.1$ & $70.8 \pm 17.8$ \\
Post test 2 & $58.3 \pm 16.8$ & $70.5 \pm 16.8$ \\
Post test 3 & $57.5 \pm 17.2$ & $68.4 \pm 16.5$ \\
Post test 4 & $63.7 \pm 17.0$ & $81.1 \pm 17.0$ \\
\hline
\end{tabular}

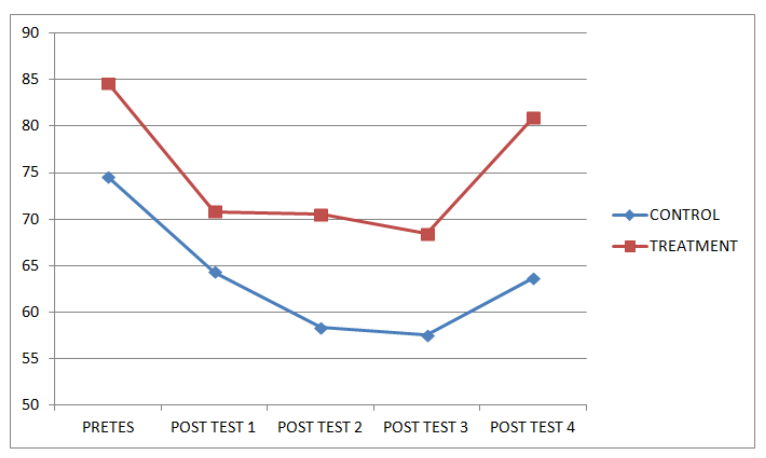

Fig. 2. Leg muscle strength.

The result of paired $t$ test of knee joint ROM in control group showed decreased ROM after 1 hour, 24 hours, 48 hours and 72 hours post eccentric activity. However at 72 hours an increase in ROM from 24 hours and 48 hours. In treatment group, the decline in ROM also occurred at 1 hour, 24 hours, 48 hours and 72 hours after eccentric activity. However, at 72 hours, the increase occurred from 1 hour, 24 hours and 48 hours (Fig. 3, Table 5).
Table 3. Paired t test of leg muscle strength in control and treatment groups

\begin{tabular}{lcc}
\hline \multicolumn{1}{c}{ Variables } & $\begin{array}{c}\text { Control } \\
\mathrm{p}(\mathrm{sig})\end{array}$ & $\begin{array}{c}\text { Treatment } \\
\mathrm{p}(\mathrm{sig})\end{array}$ \\
\hline Pre test - post test 1 & 0.000 & 0.000 \\
Pre test - post test 2 & 0.000 & 0.000 \\
Pre test - post test 3 & 0.000 & 0.000 \\
Pre test - post test 4 & 0.000 & 0.018 \\
Post test 1 - post test 2 & 0.013 & 0.869 \\
Post test 1 - post test 3 & 0.007 & 0.243 \\
Post test 1 - post test 4 & 0.768 & 0.000 \\
Post test 2 - post test 3 & 0.083 & 0.001 \\
Post test 2 - post test 4 & 0.000 & 0.000 \\
Post test 3 - post test 4 & 0.000 & 0.000 \\
\hline
\end{tabular}

The results of 2-sample independent $t$ test between control and treatment groups showed differences in leg muscle strength and knee joint ROM after eccentric activity in treatment group (receiving glutamine) and control group (receiving mineral water).

Table 4. Descriptive test of knee joint ROM (degree)

\begin{tabular}{ccc}
\hline ROM & Control & Treatment \\
\hline Pretest & $132.3 \pm 3.9$ & $132.5 \pm 3.7$ \\
Post test 1 & $127.7 \pm 3.1$ & $128.5 \pm 3.7$ \\
Post test 2 & $122.8 \pm 3.3$ & $124.3 \pm 3.3$ \\
Post test 3 & $121.2 \pm 3.2$ & $124.0 \pm 3.2$ \\
Post test 4 & $124.3 \pm 3.2$ & $131.7 \pm 4.1$ \\
\hline
\end{tabular}

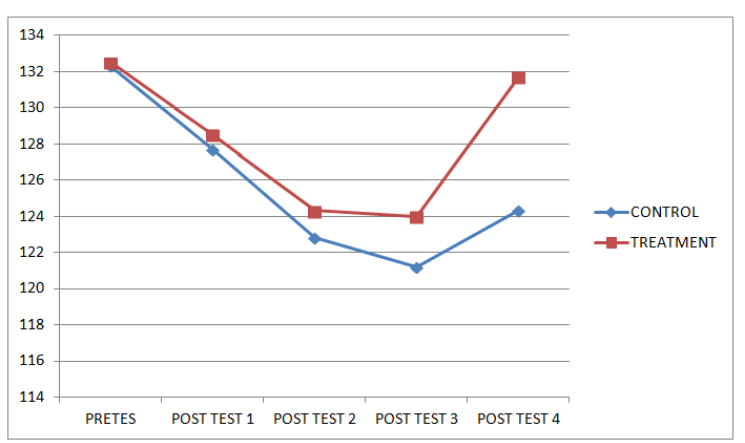

Fig. 3. Knee joint ROM.

Table 6 shows that the difference in leg muscle strength 1 hour after and before activity between control and treatment groups did not differ significantly $(\mathrm{p}=0.129)$. At 24 hours after eccentric activity, leg muscle strength between control and treatment groups also did not differ significantly. This was indicated by delta 5 with $\mathrm{p}$ value 0.078. It also occurred 48 hours after eccentric activity, when leg muscle strength between control and treatment groups also did not differ significantly, as indicated by delta 6 with $\mathrm{p}=0.161$. But at 72 hours after eccentric activity, leg muscle strength between control and 
treatment groups also differed significantly, as indicated by delta 7 with $p=0.000$. Therefore, it can be concluded that the administration of glutamine after eccentric activity increases leg muscle strength at 72 hours more than with mineral water delivery.

Table 5. Paired t test of knee joints ROM in control and treatment groups

\begin{tabular}{lcc}
\hline \multicolumn{1}{c}{ Variables } & $\begin{array}{c}\text { Control } \\
\mathrm{p}(\mathrm{sig})\end{array}$ & $\begin{array}{c}\text { Treatment } \\
\mathrm{p}(\mathrm{sig})\end{array}$ \\
\hline Pre test - post test 1 & 0.000 & 0.000 \\
Pre test - post test 2 & 0.000 & 0.000 \\
Pre test - post test 3 & 0.000 & 0.000 \\
Pre test - post test 4 & 0.000 & 0014 \\
Post test 1 - post test 2 & 0.000 & 0.000 \\
Post test 1 - post test 3 & 0.000 & 0.000 \\
Post test 1 - post test 4 & 0.000 & 0.000 \\
Post test 2 - post test 3 & 0.000 & 0.409 \\
Post test 2 - post test 4 & 0.054 & 0.000 \\
Post test 3 - post test 4 & 0.000 & 0.000 \\
\hline
\end{tabular}

Difference of knee joint ROM $1 \mathrm{~h}$ after and before activity between control and treatment group did not show significance with $\mathrm{p}$ value of 0.518 . In $24 \mathrm{~h}$ after eccentric activity, knee joint ROM between control and treatment group was not significantly different. This was indicated by delta 5 with a value of $p=0.368$, while at 48 hours after eccentric activity, knee joint ROM between control group and treatment group differed significantly. This was indicated by delta 6 with $\mathrm{p}=0.011$. It also happens at 72 hours after eccentric activity, knee joint ROM between control group and treatment group differed significantly, as indicated by delta 7 with $p=0.000$. It can therefore be concluded that, compared with mineral water, the administration of glutamine after eccentric activity does not produce higher increase of knee joint ROM at 48 hours, but does it 72 hours.

\section{DISCUSSION}

Eccentric activity is one type of resistance activity that often cause pain and muscle damage. This is because when performing the eccentric activity the muscle undergoes maximum elongation in order to produce maximum power (Burnley et al 2010). In this study, paired $\mathrm{t}$ test in the treatment group showed that leg muscle strength between 1 hour and 24 hours after eccentric activity showed no significant difference $(p=0.869)$. After 1 hour of eccentric activity the treatment group in this study received glutamine intake of 0.4 grams $/ \mathrm{kg} / \mathrm{day}$. Thus, at 24 hours after the administration of glutamine muscle strength had not been able to increase. Then, paired t test on leg muscle strength of treatment group between 1 hour and 48 hours after eccentric activity showed no significant difference $(p=0.243)$. After the administration of glutamine at 1 hour and 24 hours after eccentric activity, the mean leg muscle strength still had not been able to increase. Whereas, paired t test on leg muscle strength of treatment group between 1 hour and 72 hours after eccentric activity showed significant difference $(\mathrm{p}=0.000)$. After the administration of glutamine at 1 hour, 24 hours and 48 hours after eccentric activity, the mean leg muscle strength was increased (Fig 2). Therefore, it can be concluded that glutamine intake can increase muscle strength at 72 hours after eccentric activity.

In the body glutamine is synthesized in the metabolism of amino acids and adequate amino acid intake will affect the use and release of glutamine after eccentric activity (Parry et al 1990). Glutamine also plays a role in the formation of collagen (via proline synthesis), nucleotides (via pyrimidine and purine synthesis) and phospholipids. These three elements are very important in the manufacture of new cells. In addition, glutamine will provide alpha-ketoglutarate that enters into the krebs cycle as oxidative fuel for cells that multiply rapidly. Therefore, glutamine will accelerate the replacement or repair of tissue on body parts damaged by illness or injury (BPOM 2008).

Increased muscle protein synthesis and decreased muscle protein breakdown result in a positive muscle protein balance (Hulmi et al, 2010) which is required over a period of time to replace damaged muscle protein or to build muscle protein (regeneration). Muscle regeneration is very important to help reduce the decrease in muscle strength after eccentric activity (Jackman 2011). ROM is affected by the flexibility of muscles and muscle groups that surround the joints. If muscle flexibility is lacking, joints can not perform ROM fully. In addition, ROM is also influenced by several factors, such as joint mobility and ligament capsules, fascia, and muscle strength (Luttgens \& Hamilton 1997). Swelling, inflammation and disturbances in myofibrils after eccentric activity leads to an increase in passive muscle stiffness that results in decreased ROM in the affected joints (Willoughby 2003). 
